\title{
Microbial contamination level of air in animal waste utilization plants
}

\author{
Anna Chmielowiec-Korzeniowska', Leszek Tymczyna', Agata Drabik', Łukasz Krzosek' \\ ${ }^{1}$ Department of Animal Hygiene and Environment, University of Agriculture in Lublin, Poland
}

Chmielowiec-Korzeniowska A, Tymczyna L, Drabik A, Krzosek $Ł$. Microbial contamination level of air in animal waste utilization plants. Ann Agric Environ Med. 2016; 23(1): 54-58. doi: 10.5604/12321966.1196852

\begin{abstract}
Objective. The aim of this research was evaluation of microbial contamination of air within and in the vicinity of animal waste disposal plants.

Materials and method. Air samples were analyzed to determine total bacterial and fungal counts as well as microbial species composition. Measurements of climate conditions (temperature, humidity, air motion) and total dust concentration were also performed.

Results. Total numbers of bacteria and fungi surpassed the threshold limit values for production halls. The most abundant bacteria detected were those consisting of physiological microflora of animal dermis and mucosa. Fungal species composition proved to be most differentiated in the air beyond the plant area. Aspergillus versicolor, a pathogenic and allergenic filamentous fungus, was isolated only inside the rendering plant processing hall.

Conclusions. The measurement results showed a low sanitary-hygienic state of air in the plant processing halls and substantial air pollution in its immediate vicinity.
\end{abstract}

Key words

animal waste utilization plants, microbial contamination

\section{INTRODUCTION}

Safe processing of animal by-products in utilization plants eliminates epidemiological hazards, protects the natural environment against pathogens and facilitates obtaining meat and bone meal (MBM), as well as rendered animal fat. Hence, the entire utilization process of inedible animal products that starts with the fallen stock collection and ends with incineration, has an important sanitary-hygienic, proecological and economic function. However, at the same time, the operation of rendering plants can be considered hazardous to the environment. Such facilities, despite veterinary supervision and regulations of environmental protection agencies, can create a serious danger for sanitaryepidemiological well-being. The processed waste may be a source and also a growth medium for microbial development. One of the main routes of bacteria and fungi transmission is through the air, but this is not a natural environment for bacterial development. The presence of microbes in the air is only temporary and associated with the effect of other factors, e.g. air motion, dust, temperature, humidity and an outdoor air quality which is a source of microflora [1].

\section{OBJECTIVE}

The objective of the study was to assess the microbial contamination of air within and in the immediate vicinity of a plant for animal waste disposal.

Address for correspondence: Anna Chmielowiec-Korzeniowska Department of Animal Hygiene and Environment, University of Agriculture in Lublin, Akademicka 13, 20-950 Lublin, Poland

E-mail: anna.korzeniowska@up.lublin.pl

Received: 28 October 2013; accepted: 26 March 2014

\section{MATERIALS AND METHOD}

The study was conducted in a processing plant which, just like $60 \%$ of disposal plants registered, belongs to small utilization facilities. Three-month plant productivity is 500-600 tons of waste. The common wastes disposed of in the plant are animal cadavers or slaughter offals (ca.150 tons/month) or animal by-products (ABPs). The ABPs are classified into three categories: 1 ) $-52.2 \%, 2)-21.8 \%$ and 3 ) $-26.0 \%$, and according to the EU regulations, animal by-products are not segregated; therefore, they constitute Category I, i.e. specified risk material. The majority of tissue processed come from meat industry (92.4\%), from slaughterhouses and butchers, the poultry industry (3.4\%) and finally, the dairy industry (2.2\%).

Technological process for animal waste management in the plant comprises the following stages: collection of animal waste, transportation, waste weighing, cleaning, washing, disinfection of transportation means after unloading, animal waste crushing into particles smaller than $5 \mathrm{~cm}$ in the dissection room, sterilization of offal in destructors, separation of MBM from the fat, storage of animal meal in a store hall and fat in containers, and finally, the sale of the end products.

In accordance with the law, the sterilization of raw material should be carried out at $133^{\circ} \mathrm{C}$, under 3 bar pressure for 20 minutes, and the material crushed down to a uniform particle size of $5 \mathrm{~cm}$. In the storage hall, meat and bone meal is stored in 500-700 kg bags (BIG-BAG) placed on pallets, and fat in specially designed airtight containers.

To completely avoid cross-contamination from raw animal by-products to sterilized derivative products, the architectural design of the plant provides a physical separation between the 'clean' and 'dirty' area. The plant also has its own waste water biotreatment system in which all process water is treated before being discharged. 
Assessment of air microbial contamination included the determination of total bacterial and fungal counts and their identification. The study was conducted in the spring-summer season (May-July) and autumn-winter period (OctoberDecember) in 10 successive series. Air samples were collected inside the plant and at 4 points $100 \mathrm{~m}$ from its boundary, in the 'dirty' areas: 1) in the dissection room, in the 'clean' areas - 2) destructor hall, 3) $10 \mathrm{~m}$ from the waste water treatment plant, and 4) beyond the plant - $100 \mathrm{~m}$ from the plant boundary.

Evaluation of air microbial contamination was performed in accordance with the Polish Standard PN-EN 13098 (2007) [2] using the aspiration procedure, an air sampling pump GilAir 5 (Sensidyne, Inc., Clearwater, USA). Airborne microorganisms were collected on sterile polycarbonate filters in filter cassettes $(37 \mathrm{~mm}, 0.8 \mathrm{~mm}$; Millipore Ireland B.V., Carrigtwohill, Ireland) with the pump calibrated to an airflow of $2.0 \mathrm{l} / \mathrm{min}$. The measuring sets were calibrated before each sampling procedure using a Gillibrator 2 calibrator (Sensidyne, Inc., Clearwater, USA). The equipment was placed at the height of 1.5 meters above the floor. The sampling took 4 hours and were collected in 2 repetitions.

The total number of bacteria and microscopic fungi were estimated by the dilution plate method, with surface inoculation onto suitable growth media: tryptic soy agar (TSA) with $5 \%$ sheep blood to determine total bacterial count, and malt extract agar medium (MEA) for total fungal numbers. The air samples inoculated onto the TSA medium were incubated for 7 days at $37^{\circ} \mathrm{C}$ ( 1 day), $22^{\circ} \mathrm{C}$ ( 3 days) and $4^{\circ} \mathrm{C}$ ( 3 days), and onto the MEA medium at $30^{\circ} \mathrm{C}$ ( 4 days) and $25^{\circ} \mathrm{C}$ ( 3 days).

After completion of the incubation, the microbe colonies grown on each medium were macro- and microscopically assayed. The number of morphological types was then established and a concentration in $1 \mathrm{~m}^{3}$ of the air sample estimated and expressed in colony forming units $\left[\mathrm{CFU} / \mathrm{m}^{3}\right]$. The bacterial isolates were identified using the microscopic method and biochemical assays, i.e. API tests (bioMerieux, Warsaw, Poland).

The concomitant measurements of climate conditions were taken and included temperature-humidity indices measured with a thermohygrometer (RT811E, Technik, Warsaw, Poland), and air motion with an anemometer (A-1200M1, OBRAiUP, Lodz, Poland). Total dust concentration was estimated with a gravimetrical method via an aspirator (224PCEX8, SKC, Dorset, England). Airborne particulate mass were collected on a glass fibre filter (Whatman GF) with $37 \mathrm{~mm}$ diameter (Whatman Int. Ltd., Kent, England) with the pump calibrated to an airflow of $4.0 \mathrm{l} / \mathrm{min}$.

The obtained results were analyzed statistically and characterized with arithmetical mean $(\mathrm{M})$ and the range of values determined. Statistical analysis was conducted according to the nonparametric Mann-Whitney test with statistical software SAS v. 9.1.

\section{RESULTS}

The study was carried out in the spring-summer season when the mean air temperature reached $17.7^{\circ} \mathrm{C}$, with the peak value of $23.5^{\circ} \mathrm{C}$ (Tab.1), and in the autumn-winter period with the outdoor temperature ranging between $1.5^{\circ} \mathrm{C}-$ $7.5^{\circ} \mathrm{C}$. The observed differences were statistically significant $\mathrm{p}<0.1$. In the sampling site $100 \mathrm{~m}$ from the plant boundary,
Table 1. Macroclimate and dustiness around the plant

\begin{tabular}{lcccc}
\hline Sampling locations & $\begin{array}{c}\text { Temperature } \\
{\left[{ }^{\circ} \mathrm{C}\right]}\end{array}$ & $\begin{array}{c}\text { Humidity } \\
{[\%]}\end{array}$ & $\begin{array}{c}\text { Air motion } \\
{[\mathrm{m} / \mathrm{s}]}\end{array}$ & $\begin{array}{c}\text { Dust } \\
\text { concentration } \\
{\left[\mathrm{mg} / \mathrm{m}^{3}\right]}\end{array}$ \\
\hline 100 m of the plant & $\begin{array}{c}13.4 \\
(1.5-23.1)\end{array}$ & $\begin{array}{c}74.0 \\
(51.5-88.0)\end{array}$ & $\begin{array}{c}2.6 \mathrm{~A} \\
(0.1-23.0)\end{array}$ & $\begin{array}{c}2.1 \\
(0.5-4.8)\end{array}$ \\
\hline Summer & $\begin{array}{c}20.5 \mathrm{~A} \\
(17.7-23.1)\end{array}$ & $\begin{array}{c}68.6 \\
(51.5-82.6)\end{array}$ & $\begin{array}{c}0.4 \\
(0.1-0.7)\end{array}$ & $\begin{array}{c}2.9 \\
(1.6-4.8)\end{array}$ \\
\hline Winter & $6.3 \mathrm{~A}$ & 79.0 & 4.8 & 1.2 \\
\hline $10 \mathrm{~m}$ of the sewage & $(1.5-7.5)$ & $(75.6-88.0)$ & $(0.2-23.0)$ & $(0.5-4.3)$ \\
treatment facility & $(4.2-23.5)$ & $(52.7-83.3)$ & $(0-13.5)$ & $(0-3.4)$ \\
\hline Summer & $21.6 \mathrm{~B}$ & $64.1 \mathrm{~A}$ & $0.1 \mathrm{a}$ & $1.3 \mathrm{a}$ \\
\hline Winter & $(18.3-23.5)$ & $(52.7-73.4)$ & $(0-0.1)$ & $(0-3.1)$ \\
\hline
\end{tabular}

a - values denoted with the same letters in columns are different at $p<0.05$

$A, B$ - values denoted with the same letters in columns are different at $p<0.01$

Table 2. Average concentration of bacteria and fungi in outdoor environment around the plant

\begin{tabular}{lcc}
\hline Sampling locations & $\begin{array}{c}\text { Total bacteria } \\
{\left[\mathrm{CFU} / \mathrm{m}^{3}\right]}\end{array}$ & $\begin{array}{c}\text { Total fungi } \\
{\left[\mathrm{CFU} / \mathrm{m}^{3}\right]}\end{array}$ \\
\hline 100 m of the plant & $\begin{array}{c}4.7 \times 10^{6} \\
\left(5.2 \times 10^{2}-4.3 \times 10^{7}\right)\end{array}$ & $\begin{array}{c}2.2 \times 10^{5} \mathrm{a} \\
\left(4.0 \times 10^{1}-5.6 \times 10^{5}\right)\end{array}$ \\
\hline Summer & $\begin{array}{c}9.3 \times 10^{6} \mathrm{~A} \\
\left(8.3 \times 10^{4}-4.3 \times 10^{7}\right)\end{array}$ & $\begin{array}{c}2.9 \times 10^{5} \\
\left(1.7 \times 10^{4}-5.6 \times 10^{5}\right)\end{array}$ \\
\hline Winter & $\begin{array}{c}6.0 \times 10^{3} \mathrm{~A} \\
\left(5.2 \times 10^{2}-2.5 \times 10^{4}\right)\end{array}$ & $\begin{array}{c}2.5 \times 10^{4} \\
\left(4.0 \times 10^{1}-5.0 \times 10^{4}\right)\end{array}$ \\
\hline $10 \mathrm{~m}$ of the sewage treatment & $\begin{array}{c}2.0 \times 10^{7} \\
\left(5.2 \times 10^{2}-1.5 \times 10^{8}\right)\end{array}$ & $\begin{array}{c}1.4 \times 10^{4} \mathrm{a} \\
\left(0-5.8 \times 10^{4}\right)\end{array}$ \\
\hline facility & $4.0 \times 10^{7}$ & $2.0 \times 10^{4}$ \\
Summer & $\left(8.3 \times 10^{3}-1.5 \times 10^{8}\right)$ & $\left(0-5.8 \times 10^{4}\right)$ \\
\hline Winter & $2.5 \times 10^{5}$ & $2.8 \times 10^{3}$ \\
& $\left(5.2 \times 10^{2}-8.3 \times 10^{5}\right)$ & $\left(0-8.3 \times 10^{3}\right)$ \\
\hline
\end{tabular}

a - values denoted with the same letters in columns are different at $p<0.05$

$A$ - values denoted with the same letters in columns are different at $p<0.01$

Table 3. Microclimate and dustiness inside the plant

\begin{tabular}{lcccc}
\hline Sampling locations & $\begin{array}{c}\text { Temperature } \\
{\left[{ }^{\circ} \mathrm{C}\right]}\end{array}$ & $\begin{array}{c}\text { Humidity } \\
{[\%]}\end{array}$ & $\begin{array}{c}\text { Air motion } \\
{[\mathrm{m} / \mathrm{s}]}\end{array}$ & $\begin{array}{c}\text { Dust } \\
\text { concentration } \\
{\left[\mathrm{mg} / \mathrm{m}^{3}\right]}\end{array}$ \\
\hline Dissection room & $\begin{array}{c}16.1 \\
(2.4-31.6)\end{array}$ & $\begin{array}{c}64.0 \\
(32.0-88.8)\end{array}$ & $\begin{array}{c}0.3 \mathrm{~A} \\
(0.1-0.6)\end{array}$ & $\begin{array}{c}2.5 \\
(0.7-4.7)\end{array}$ \\
\hline Summer & $\begin{array}{c}26.0 \mathrm{~A} \\
(20.7-31.6)\end{array}$ & $\begin{array}{c}48.8 \mathrm{~A} \\
(32.0-61.3)\end{array}$ & $\begin{array}{c}0.4 \mathrm{a} \\
(0.2-0.6)\end{array}$ & $\begin{array}{c}2.0 \\
(0.7-4.7)\end{array}$ \\
\hline Winter & $\begin{array}{c}\text { 6.2 A } \\
(2.4-7.4)\end{array}$ & $\begin{array}{c}79.1 \mathrm{~A} \\
(76.1-88.8)\end{array}$ & $\begin{array}{c}0.2 \mathrm{a} \\
(0.1-0.3)\end{array}$ & $\begin{array}{c}3.1 \\
(3.0-3.3)\end{array}$ \\
\hline Destructor hall & 22.5 & 50.3 & $0.1 \mathrm{~A}$ & 2.5 \\
\hline \multirow{2}{*}{ Summer } & $(16.1-30.3)$ & $(34.0-61.1)$ & $(0-0.1)$ & $(1.8-4.4)$ \\
\hline Winter & $27.1 \mathrm{~B}$ & 46.1 & 0.1 & $2.8 \mathrm{a}$ \\
& $(24.1-30.3)$ & $(39.0-52.7)$ & $(0-0.1)$ & $(1.8-4.4)$ \\
\hline
\end{tabular}

a - values denoted with the same letters in columns are different at $p<0.05$

$A, B$ - values denoted with the same letters in columns are different at $p<0.01$

significant differences were also noted while comparing the values of summer and winter measurements of humidity and air motion. The higher temperature values, with a maximum of $31.6^{\circ} \mathrm{C}$, were determined in the closed spaces (Tab. 3). The temperature in the dissection room was close to those noted within the sewage treatment plant. 
Table 4. Average concentration of bacteria and fungi in indoor air of the plant

\begin{tabular}{lcc}
\hline Sampling locations & $\begin{array}{c}\text { Total bacteria } \\
{\left[\mathrm{CFU} / \mathrm{m}^{3}\right]}\end{array}$ & $\begin{array}{c}\text { Total fungi } \\
{\left[\mathrm{CFU} / \mathrm{m}^{3}\right]}\end{array}$ \\
\hline Dissection room & $\begin{array}{c}1.9 \times 10^{6} \\
\left(3.2 \times 10^{2}-1.0 \times 10^{7}\right)\end{array}$ & $\begin{array}{c}2.0 \times 10^{4} \\
\left(0-3.3 \times 10^{4}\right)\end{array}$ \\
\hline Summer & $\begin{array}{c}3.7 \times 10^{6} \mathrm{~A} \\
\left(3.3 \times 10^{5}-1.0 \times 10^{7}\right)\end{array}$ & $\begin{array}{c}2.2 \times 10^{4} \\
\left(0-3.3 \times 10^{4}\right)\end{array}$ \\
\hline Winter & $\begin{array}{c}7.2 \times 10^{3} \mathrm{~A} \\
\left(3.2 \times 10^{2}-3.3 \times 10^{4}\right)\end{array}$ & $\begin{array}{c}1.7 \times 10^{4} \\
\left(8.0 \times 10^{1}-3.3 \times 10^{4}\right)\end{array}$ \\
\hline Destructor hall & $1.2 \times 10^{8}$ & $3.6 \times 10^{4}$ \\
Summer & $\left(3.6 \times 10^{2}-1.1 \times 10^{9}\right)$ & $\left(0-1.7 \times 10^{5}\right)$ \\
\hline Winter & $2.3 \times 10^{8} \mathrm{a}$ & $4.8 \times 10^{4}$ \\
& $\left(5.8 \times 10^{4}-1.1 \times 10^{9}\right)$ & $\left(0-1.7 \times 10^{5}\right)$ \\
\hline
\end{tabular}

$a-$ values denoted with the same letters in columns are different at $p<0.05$

A - values denoted with the same letters in columns are different at $p<0.01$

Beyond the plant area, increased air motion was recorded, especially in the autumn-winter season when mean air velocity increased by $2.2 \mathrm{~m} / \mathrm{s}(\mathrm{p}<0.05)$, compared to the summer period. In the confined spaces, significantly higher (mean by $0.2 \mathrm{~m} / \mathrm{s}$ ) air velocity values were established in the dissection room $(\mathrm{p}<0.01)$. High air dust concentration was determined in the destructor hall in summer and within the sewage biotreatment device area in winter. In the destructor hall in summer, a significantly higher concentration of total dust was found, compared to the season with lower temperatures $(\mathrm{p}<0.05)$.

Total bacterial and fungal numbers showed a difference dependent on the sampling location and season (Tab. 2, 4). In the summer period in all of the studied sites, the concentration of microorganisms, both bacteria and fungi, was higher compared with the autumn-winter season. Irrespective of season, a higher microbial contamination rate was detected in the air of the destructor hall. The highest numbers of bacteria were determined in the dissection room $(\mathrm{p}<0.01)$ and destructor hall $(\mathrm{p}<0.05)$ during the higher air temperature period.

Smaller fluctuations were observed when comparing the fungal contamination levels, with the highest fungal load detected in the atmospheric air $100 \mathrm{~m}$ from the plant boundary $(\mathrm{p}<0.05)$. At the other sites, fungal bioaerosol concentration was at a similar level, and declined slightly in the autumn-winter season.

The percentage of each microbial group changed along with the sampling location and season of the year (Fig. 1). Gramnegative bacteria was not detected in the air. However, within the sewage biotreatment unit area in the winter period, Gram-positive corynebacteria dominated, which accounted for as much as $94 \%$ of all isolated bacteria. At the same site in summer, Gram-positive cocci shared an increase of up to $46 \%$.

In the production halls, Gram-positive cocci constituted most of the recovered bacteria and their share grew during the higher temperature period. Only in the dissection room, the Gram-positive cocci count in the summer season was lower by $13 \%$, compared to the winter period. The in-plant air assessment showed the presence of Gram-negative bacteria, which were most abundant in the dissection room during the summer period where they made up $8 \%$ of all bacteria identified in the air.

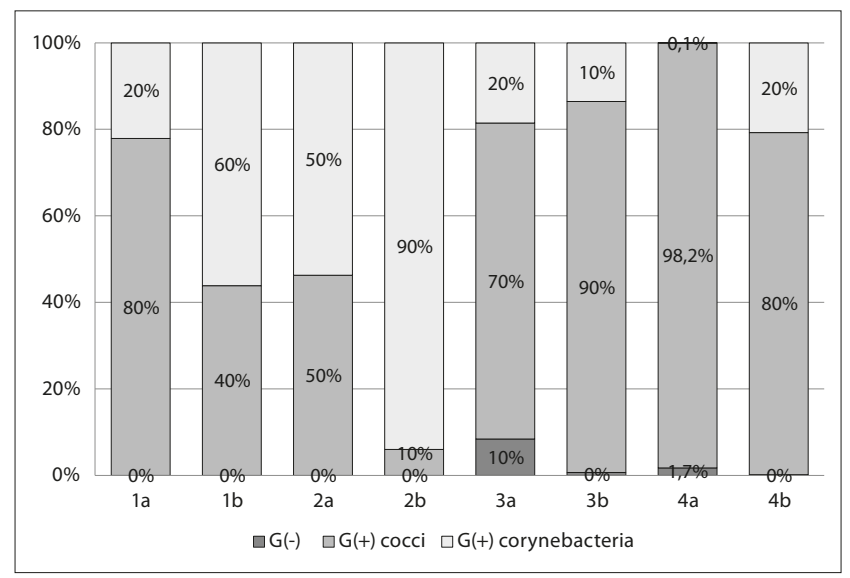

Figure 1. Percentage of each bacterial group in the examined air. Sampling locations: $100 \mathrm{~m}$ from the plant - 1a) summer, 1b) winter; $10 \mathrm{~m}$ from the sewage treatment facility - 2a) summer, $2 b$ ) winter; dissection room - 3a) summer, 3b) winter; destructor hall - 4a) summer, 4b) winter

From the collected air samples, 12 different taxa were isolated, within which 14 species were determined (Tab. 5). The most ubiquitous were Gram-positive bacteria - cocci and corynebacteria (4 and 5 taxa, respectively).

Bacteria from the genera Micrococcus, Brevibacterium and species Staphylococcus xylosus were recovered from the air

Table 5. Bacterial species and genera identified in air samples collected on the plant

\begin{tabular}{lccc}
\hline Genera/species & $\begin{array}{c}10 \mathrm{~m} \text { of the } \\
\text { sewage } \\
\text { the plant }\end{array}$ & $\begin{array}{c}\text { Dissection } \\
\text { treatment } \\
\text { facility }\end{array}$ & $\begin{array}{c}\text { Destructor } \\
\text { room }\end{array}$ \\
\hline
\end{tabular}

\section{$\mathrm{G}(-)$ bacteria}

\begin{tabular}{lllll}
\hline Neisseria meningitidis (I) & - & - & - & + \\
\hline Neisseria subflava & - & - & - & + \\
\hline Haemophilus parainfluenzae (I) & - & - & + & + \\
\hline Sphingomonas paucimobilis & - & - & + & + \\
\hline
\end{tabular}

$\mathrm{G}(+)$ cocci

\begin{tabular}{|c|c|c|c|c|}
\hline Staphylococcus spp. & + & + & - & + \\
\hline Staph. xylosus & + & + & + & + \\
\hline Staph. epidermidis & + & - & + & + \\
\hline Staph. saprophyticus & - & - & + & + \\
\hline Staph. sanguinis & - & + & + & + \\
\hline Kocuria varians & + & + & - & - \\
\hline Kocuria kristinae & + & + & - & - \\
\hline Micrococcus spp. & + & + & + & + \\
\hline Micrococcus luteus & + & + & - & - \\
\hline Aerococcus viridans & + & + & - & + \\
\hline \multicolumn{5}{|l|}{ Gram(+) corynebacteria } \\
\hline Cellulomonas spp. & + & - & + & + \\
\hline Corynebacterium spp. (AL) & - & + & + & + \\
\hline Corynebacterium strictum & - & + & + & - \\
\hline Corynebacterium urealiticum & + & + & - & - \\
\hline Arthrobacter spp. & - & + & + & + \\
\hline Mycobacterium spp. (I, AL) & - & + & - & + \\
\hline Brevibacterium spp. (AL) & + & + & + & + \\
\hline
\end{tabular}

(+) - present; (-) absent; Activity: AL- allergenic, I- infectious 
Table 6. Fungal species and genera identified in air samples collected on the plant

\begin{tabular}{|c|c|c|c|c|}
\hline Genera/species & $\begin{array}{l}100 \mathrm{~m} \text { of } \\
\text { the plant }\end{array}$ & $\begin{array}{c}10 \mathrm{~m} \text { of the } \\
\text { sewage } \\
\text { treatment } \\
\text { facility }\end{array}$ & $\begin{array}{l}\text { Dissection } \\
\text { room }\end{array}$ & $\begin{array}{l}\text { Destructor } \\
\text { hall }\end{array}$ \\
\hline Penicillium spp. (AL, T) & + & + & + & - \\
\hline Penicillium chrysogenum & + & - & - & - \\
\hline Aspergillus versicolor $(\mathrm{AL}, \mathrm{T})$ & - & - & + & - \\
\hline Aspergillus clavatus (AL) & - & + & - & - \\
\hline Fusarium sp (T) & + & - & - & - \\
\hline Cladosporium spp. (AL) & + & + & + & - \\
\hline Cladosporium macrocarpum & + & + & + & + \\
\hline Ulocladium chartarum & + & - & - & + \\
\hline Acremonium spp. & - & - & + & - \\
\hline Acremonium chorticola & + & - & - & - \\
\hline Acremonium strictum & + & + & - & + \\
\hline Botryotrichum spp. & - & - & + & - \\
\hline Phomopsis spp. & + & + & + & - \\
\hline Yeasts & + & - & + & + \\
\hline
\end{tabular}

+ - present; - absent; Activity: AL - allergenic; T - toxic

samples collected from all studied locations. Two species of bacteria belonging to the genus Neisseria were isolated only in the air of the destructor hall. Staphylococcus saprophyticus, Haemophilus parainfluenzae and Sphingomonas paucimobilis were present exclusively in the air in the plant halls, while Kocuria sp. and Micrococcus luteus, Aerococcus viridans and Corynebacterium urealiticum were detected only in the atmospheric air.

As for fungi, 9 taxa were isolated -7 species (Tab. 6). Atmospheric air was found to be most differentiated with regards to fungal species. The following were isolated only in the air samples collected outside the plant: Penicillium chrysogenum, Aspergillus clavatus, Acremonium chorticola and the genus Fusarium. Only in the dissection room air, the presence of Aspergillus versicolor, as well as fungi from the genus Acremonium and Botryotrichum was determined. Cladosporium macrocarpum were recovered from all the sampling locations,.

\section{DISCUSSION}

The animal processing plant under investigation is an environment in which the presence of bacteria and fungi is inevitable but, as the study indicates, occupational exposure of the workers to the bioaerosol level determined may result in adverse health effects because of the very poor air quality. The measured concentrations exceeded the threshold values set for the production halls [3]. In both the 'dirty' and 'clean' areas, i.e. the dissection room and destructor hall, the bioaerosol concentration surpassed the threshold value of occupational exposure limits defined by Malmros [3], as well as the hygiene standards presented by Dutkiewicz et al. [4] for an organic dust-contaminated workplace.

Destructors are sterilizers; hence, the action of destruction should not be a source of contamination. A high rate of indoor air microbial contamination in the destructor hall was likely to have been caused by the dustiness from the close proximity of the processed material storage hall and the secondary development of bacteria on the stored material. The level of determined contaminants was also affected by the season, primarily by humidity and air temperature. In the period of higher temperatures, doubling of the bacteria population occurred in the dissection room, compared to the winter season. Similar high levels of bacterial contamination were also established in farm buildings $[5,6]$, but were much lower in the sewage treatment facility area $[7,8]$.

From the bio-ecological standpoint, a weighty problem is that air pollutants emitted into the atmosphere by plants for dead animal utilization also deteriorate the local air quality. Monitoring around the processing plant showed that the bacterial and fungal contamination rate at the sewage treatment unit persisted at a high level, the same as in the production halls. The air samples taken $100 \mathrm{~m}$ from the plant boundary indicated only slightly lower concentrations. At this sampling location, total bacterial and fungal concentrations reached $4.7 \times 10^{6} \mathrm{CFU} / \mathrm{m}^{3}$ and $2.2 \times 10^{5} \mathrm{CFU} / \mathrm{m}^{3}$ that compared to the standards set for atmospheric air PN-89/Z-04111/02 [9] and PN-89/Z-04111/03 [10], evidenced strong biological pollution of the air.

The air microflora composition in processing plants relies largely on the state of the raw material, its sanitary-hygienic state, hygiene storage conditions and the level of the plant technology. Most microorganisms introduced with animal material, as well as those developing on the stored organic matter, are saprophytic bacteria. Therefore, bacteria from the animal physiological flora of dermis and mucous membranes dominated, i.e. those from the genus Staphylococcus, Micrococcus and Corynebacterium. Ellis at al., [11] report that during the early stage of meat spoilage, mainly Gram-positive bacteria develop, usually represented by micrococci followed by lactic acid bacteria. A specific bacterium identified in the production hall air was Staphylococcus saprophyticus - a leading cause of human urinary tract infection. However, this species was not isolated from the atmospheric air samples, which implies that raw material undergoing the utilization process may be its major source.

Of the Gram-negative bacteria isolated solely in the air of the production halls, two species of pathogenic bacteria producing severe symptoms of infections identified Neisseria meningitidis and Haemophilus parainfluenzae. Most probably their presence was not caused by plant activity because, as indicated, humans are the natural reservoir of these bacteria.

Among the in-plant air samples, bacteria from the genus Corynebacterium, Mycobacterium and Brevibacterium were also identified and classified into risk group 2, according to the Ordinance of the Ministry of Health of 20 April 2005 on hazardous biological agents [12]. These bacteria may therefore pose a health threat to the workers.

Another important agents increasing occupational risk of workers in the examined plant were moulds, and the fungal aerosol load determined largely exceeded the level determined even in the farm buildings and the waste water treatment facility $[13,14]$. Species composition of the identified fungi was more differentiated in the outside air, but only the air samples collected in the confined space showed the presence of Aspergillus versicolor which has well known toxic and allergic properties. Fungi occurring in the air of the halls contaminated with enzootic substances, fungi from genus Penicillum, Aspergillus and Cladosporium identified 
in the plant, may induce allergic reactions, asthma, and conjunctivitis, or contribute to the development of mycoses, especially systemic mycoses. Due to their small size, large numbers of the spores released are easily deposited in the lower airways.

Moulds are not only a source of mycotoxins but also volatile organic compounds (among others, aldehydes, ketones) which produce systemic poisonings as well as immunotoxic glucans (1,3-beta-D-glucans), glucose polymers being a component of the fungal cell wall. These molecules are responsible for the development of organic dust toxic syndrome (ODTS) and chronic bronchitis. The most common response to exposure to fungal metabolites is immunosuppression, irritation of mucous membrane of the upper airways, leading to chronic inflammation of the respiratory tract $[15,16]$.

Summing up, the utilization process of animal by-products, regardless of their source, poses a potential threat to human health and the environment. The threat reduction should involve the implementation of appropriate control measures concerning the proper location of processing plants, and essentially the complete hermetization of the utilization process in order to prevent the spread of potentially hazardous bioaerosol.

\section{REFERENCES}

1. Jones AM, Harrison RM. The effects of meteorological factors on atmospheric bioaerosol concentrations - A Review. Sci Total Environ. 2004; 326: 151-180.

2. PN-EN 13098:2007. Powietrze na stanowiskach pracy - Wytyczne dotyczące pomiaru mikroorganizmów i endotoksyn zawieszonych w powietrzu.

3. Górny R. Biologiczne czynniki szkodliwe: normy, zalecenia i propozycje wartości dopuszczalnych. Podstawy i Metodyki Oceny Środowiska Pracy. 2004; 3(41): 17-39.

4. Dutkiewicz J, Śpiewak R, Jabłoński L, Szymańska J. Biologiczne Czynniki Zagrożenia Zawodowego. Klasyfikacja, Narażone Grupy Zawodowe, Pomiary, Profilaktyka. Ad Punctum, Lublin 2007.
5. Chang CW, Chung H, Huang CF, Su HJJ. Exposure of workers to airborne microorganisms in open-air swine houses. Appl Environ Microbiol. 2001; 67: 155-161.

6. Eduard W, Douwes J, Omenaas E, Heederik D. Do farming exposures cause or prevent asthma? Results from a study of adult Norwegian farmers. Thorax. 2004; 59: 381-386.

7. Breza-Boruta B, Paluszak Z. Influence of water treatment plant on microbiological composition of air bioaerosol. Pol J Environ Stud. 2007; 16: 663-670.

8. Kołwzan B, Jadczyk P, Pasternak G, Głuszczak J, Pawlik M, Krawczyńska M. et al. Ocena stanu sanitarnego powietrza w otoczeniu wybranej oczyszczalni ścieków. Ochrona Środowiska. 2012; 34: 9-14.

9. PN-89/Z-04111/02: 2002. Ochrona czystości powietrza. Badania mikrobiologiczne. Oznaczanie liczby bakterii w powietrzu atmosferycznym (imisja) przy pobieraniu próbek metodą aspiracyjną i sedymentacyjną.

10. PN-89/Z-04111/03: 2003. Ochrona czystości powietrza. Badania mikrobiologiczne. Oznaczanie liczby grzybów mikroskopowych próbek metodą aspiracyjną i sedymentacyjną w powietrzu atmosferycznym (imisja) przy pobieraniu.

11. Ellis DI, Broadhurst D, Kell DB, Rowland JJ, Goodacre R. Rapid and quantitative detection of the microbial spoilage of meat by fourier transform infrared spectroscopy and machine learning. Appl Environ Microbiol. 2002; 68: 2822-2828.

12. Rozporządzenie Ministra Zdrowia z dnia 22 kwietnia 2005 r. sprawie szkodliwych czynników biologicznych dla zdrowia w środowisku pracy oraz ochrony zdrowia pracowników zawodowo narażonych na te czynniki. Dz. U. z dnia 11 maja 2005 r.

13. Prażmo Z, Krysińska-Traczyk E, Sitkowska J, Cholewa G, Dutkiewicz J. Exposure to bioaerosols in a municipal sewage treatment plant. Ann Agric Environ Med. 2003; 10: 241-248.

14. Szadkowska-Stańczyk I, Bródka K, Buczyńska A, Cyprowski M, Kozajda A, Sowiak M. Ocena narażenia na bioaerozole pracowników zatrudnionych przy intensywnej hodowli trzody chlewnej. Med Pr. 2010; 61: 257-269.

15. Adhikari A, Reponen T, Lee SA, Grinshpun SA. Assessment of human exposure to airborne fungi in agricultural confinements: personal inhalable sampling versus stationary sampling. Ann Agric Environ Med. 2004; 11: 269-277.

16. Smit LA, Wouters IM, Hobo MM, Eduard W, Doekes G, Heederik D. Agricultural seed dust as a potential cause of organic dust toxic syndrome. Occup Environ Med. 2006; 63: 59-67. 